Research Paper

\title{
Characterization of the spoilage lactic acid bacteria in "sliced vacuum-packed cooked ham"
}

\author{
Daneysa Lahis Kalschne ${ }^{1}$, Rute Womer ${ }^{2}$, Ademir Mattana ${ }^{2}$, Cleonice \\ Mendes Pereira Sarmento ${ }^{1}$, Luciane Maria Colla ${ }^{3}$, Eliane Colla ${ }^{1}$ \\ ${ }^{1}$ Programa de Pós-Graduação em Tecnologia de Alimentos, Universidade Tecnológica Federal do Paraná, \\ Câmpus Medianeira, Medianeira, PR, Brazil. \\ ${ }^{2}$ Laboratório de Análise de Alimentos, Universidade Tecnológica Federal do Paraná, Câmpus Medianeira, \\ Medianeira, PR, Brazil. \\ ${ }^{3}$ Laboratório de Fermentações, Curso de Engenharia de Alimentos, Faculdade de \\ Engenharia e Arquitetura, Universidade de Passo Fundo, Passo Fundo, RS, Brazil.
}

Submitted: January 7, 2013; Approved: June 9, 2014.

\begin{abstract}
The lactic acid bacteria are involved with food fermentation and in such cases with food spoilage. Considering the need to reduce the lactic acid bacteria growth in meat products, the aim of this work was to enumerated and investigated the lactic acid bacteria present on sliced vacuum-packed cooked ham stored at $4{ }^{\circ} \mathrm{C}$ and $8{ }^{\circ} \mathrm{C}$ for 45 days by phenotypic and molecular techniques. The quantification showed that the lactic acid bacteria were present from the first day with mean count of $1.98 \mathrm{log} \mathrm{cfu} / \mathrm{g}$ for the four batches analyzed. The lactic acid bacteria grew rapidly on the samples, and plate counts around $7.59 \log \mathrm{cfu} / \mathrm{g}$ and $8.25 \log \mathrm{cfu} / \mathrm{g}$ were detected after 45 days of storage at $4{ }^{\circ} \mathrm{C}$ and $8{ }^{\circ} \mathrm{C}$, respectively; storage temperatures studied showed significant influence on the microorganism in study growth. The predominant lactic acid bacteria associated with the spoilage samples at one day of storage includes Lactobacillus sp., the phenotypic overlap Leuconostoc/Weissella sp. and Enterococcus sp. At 45 days of storage at 4 and $8{ }^{\circ} \mathrm{C}$ the mainly specie was Lactobacillus curvatus, following by Lactobacillus sakei and Leuconostoc mesentereoides; the Enterococcus sp. was not present in the samples.
\end{abstract}

Key words: Lactobacillus curvatus, Lactobacillus sakei, Leuconostoc mesenteroides, spoilage.

\section{Introduction}

Cooked meat products are economically important chilling products with a high consumption in world. The shelf-life of cooked and sliced meat products, as cooked ham, is limited mainly because of microbiological safety and spoilage issues (Vercammen et al., 2011).

The meat and meat products are highly perishable, so special care should be applied during all operations, to minimize deterioration and extend the shelf-life. The meat shelf life is strictly depending on the number and type of bacteria initially present and their further growth in the ecological conditions applied during storage, particularly temperature, $\mathrm{pH}$ and gaseous atmosphere (Russo et al., 2006). The exclusion or reduction of oxygen in modified atmosphere packaging products using a barrier film prolongs the shelflife of meat by reducing oxidative rancidity and microbial growth (Audenaert et al., 2010). Whereas the combination of microaerophilic conditions, presence of $\mathrm{NaCl}, \mathrm{NaNO}_{2}$ and a reduced water activity inhibits growth of Gramnegative spoilage microbiota, favors growth of lactic acid bacteria (LAB) (Ammor et al., 2005; Hu et al., 2009; Audenaert et al., 2010).

As a result of LAB activities, acid off-flavors and off-odors, decrease in $\mathrm{pH}$, milky exudates, gas production, swelling of the pack, discoloration and/or greenish color can be observed (Jay, 2005; Hu et al., 2009; Zhang et al., 2009; Audenaert et al., 2010). Anyway, deterioration

Send correspondence to D.L. Kalschne. Postgraduate Program in Food Technology (PPGTA), Federal Technological University of Paraná, Campus Medianeira, Brasil Avenue 4232, Caixa Postal 271, 85884-000 Medianeira, PR, Brazil. E-mail: daneysa@hotmail.com, daneysa@frimesa.com.br. 
caused by LAB is primarily due to production of metabolites that cause unwanted changes in appearance, texture and flavor of the substrate (Massaguer, 2006).

LAB contribute actively in the spoilage of sliced cooked ham, where they have been identified as the main microbial group involved in the spoilage, especially in vacuum and modified atmosphere packaging (Hu et al., 2009; Slongo et al., 2009; Zhang et al., 2009; Kreyenschmidt et al., 2010; Vercammen et al., 2011).

Originally, the group of LAB included four kinds of great importance in food: Lactobacillus, Leuconostoc, Pediococcus and Streptococcus (Hall et al., 2001; Silva et al., 2010). Currently, this group consists on 15 genera (Jay, 2005; Landgraf, 2008; Silva et al., 2010).

New tools for classification and identification of LAB are currently replacing and/or complementing the traditional phenotype-based methodologies. The most promising for routine use are $16 \mathrm{~S}$ rRNA gene sequencing, PCR-based fingerprinting techniques and soluble protein patterns (Axelsson, 2004). Although the classical approach to bacterial identification based on morphological, physiological and biochemical features provides reasonable results and is easy to perform, in general these techniques are not always reliable for the identification of LAB (Stiles and Holzapfel, 1997).

Analysis of LAB is not required by Brazilian legislation for meat products, just some pathogens such as Salmonella, sulfite reducing Clostridium, Coagulase positive Staphylococcus and Coliforms at $45{ }^{\circ} \mathrm{C}$ have stipulated standards (Brazil, 2001). Although the analysis for LAB quantification and identification are of great importance for this kind of meat product, because the LAB represent a group of spoilage that cause economic losses during the shelf life of sliced vacuum-packed meat products, especially considering the shelf life of commercial brands of sliced vacuum-packed cooked ham available at supermarkets, which ranging from 30 to 60 days of storage at temperatures of $0^{\circ} \mathrm{C}$ to $8^{\circ} \mathrm{C}$.

According to this, the aim of this work was quantify and identify the predominant LAB from sliced vacuumpacked cooked ham at time 1 day and 45 days at $4{ }^{\circ} \mathrm{C}$ and $8^{\circ} \mathrm{C}$. The isolates were initially quantified by plates count, following classified according phenotypic and molecular characteristics.

\section{Materials and Methods}

\section{Collection and storage of samples}

The samples of sliced vacuum-packed cooked ham were prepared in a slaughterhouse company with conventional techniques and good manufacturing practices. The production was performed weekly during four weeks. A total of nine packages of samples were collected for each batch. A microbiological analysis was performed in triplicate on the time 1 day after the slicing and packaging of the product, and two triplicates were performed on the time 45 days of shelf life, one with storage at $4{ }^{\circ} \mathrm{C}$ and another at $8^{\circ} \mathrm{C}$. In total, 36 samples were collected. The storage of the samples with 45 days of shelf life occurred in refrigerating chamber (Totaline, Rio de Janeiro, Brazil).

\section{Isolation and enumeration of total LAB}

Quantification of LAB in the samples was realized by plating in Man Rogosa and Sharp (MRS) agar (Himedia, Mumbai, India). For all samples, three packets of sliced cooked ham per batch were used for microbiological analysis. For each package, $25 \mathrm{~g}$ portion was aseptically weighed and pooled in $225 \mathrm{~mL}$ of sterile peptone water $(0.1 \%)$ (MicroMed, produced by Isofar, Rio de Janeiro, Brazil) in a sterile plastic bag and blended with stomacher for $2 \mathrm{~min}$. Aliquots of $1 \mathrm{~mL}$ of the dilutions of the samples (up to $10^{-7}$ ) were inoculated and mixed with MRS agar, and poured an overlayer of this. The inverted plates were incubated at $30{ }^{\circ} \mathrm{C}$ for $48 \mathrm{~h}$ (Novaética, model 403-3D, São Paulo, Brazil) in normal atmosphere (Russo et al., 2006; Silva et al., 2010).

\section{Phenotypic analysis}

For the LAB identification by phenotypic characteristics, information from various researchers were collected and listed in the Table 1, and used as a basis for this differentiation. The group of LAB is relatively heterogeneous; some genera have differences in molecular levels that express single phenotypic characteristics.

The Flowchart showed in Figure 1, adapted from Schillinger and Lücke (1989), was used for the sequential analysis of phenotypic characteristics of the $12 \mathrm{LAB}$ genera studied in this work.

Triplicate plates with typical LAB growth colonies were randomly selected and five colonies of each were tested by phenotypic characteristics. The proposed flowchart (Figure 1) identifies the most of genera 12 listed, but there are overlaps between the genera and exceptions to rules can be found, especially when dealing with the genera Lactobacillus (heterofermentatives), Leuconostoc and Weissella, Lactobacillus (homofermentatives) and Brochothrix, and also with Lactococcus and Vagococcus. Because this, molecular analyzes were performed in parallel to identify the genus and species at time 45 days.

Phenotypic characteristics were tested as follows: each colony was aseptically transferred to a tube with MRS broth (Himedia, Mumbai, India) supplemented with $5 \%$ of glucose and an inverted Durham tube incubated at $30{ }^{\circ} \mathrm{C}$ for $48 \mathrm{~h}$ for test the gas production from glucose (Potes and Marinho, 2007; Wu et al., 2012); after aliquots of the tube of gas production from glucose were tested for Gram reaction (Oliveira et al., 2008; Silva et al., 2010). From this point the tests were performed following the sequence of classification according to the flowchart proposed (Figure 1) and all the test were performed by aliquots of the test 
Table 1 - Key phenotypic characteristics of LAB.

\begin{tabular}{|c|c|c|c|c|c|c|c|c|c|}
\hline Genera & Morphology & $\begin{array}{c}\mathrm{CO}_{2} \text { from } \\
\text { glucose }\end{array}$ & $\begin{array}{l}\text { Lactic acid } \\
\text { isomer }\end{array}$ & $\begin{array}{c}\text { Growth at } \\
10^{\circ} \mathrm{C}\end{array}$ & $\begin{array}{l}\text { Growth at } \\
45^{\circ} \mathrm{C}\end{array}$ & $\begin{array}{l}\text { Growth in } \\
18 \% \mathrm{NaCl}\end{array}$ & $\begin{array}{c}\text { Growth } \\
\text { at pH } 4.4\end{array}$ & $\begin{array}{c}\text { Growth } \\
\text { at } \mathrm{pH} 4.5\end{array}$ & $\begin{array}{l}\text { Catalase } \\
\text { activity }\end{array}$ \\
\hline \multirow[t]{3}{*}{ Aerococcus } & $\mathrm{C}^{\mathrm{a}}(2)$ & $-(2)$ & L (2) & $+(2)$ & $-(2)$ & $-(2)$ & $-(2)$ & & $-(1)$ \\
\hline & $C^{\mathrm{a}}(10)$ & $-(10)$ & $\mathrm{L}(10)$ & $+(10)$ & $-(10)$ & $-(10)$ & $-(10)$ & & \\
\hline & $C^{\mathrm{a}}(23)$ & $-(23)$ & L (23) & $+(23)$ & $-(23)$ & $-(23)$ & $-(23)$ & & \\
\hline \multirow[t]{2}{*}{ Atopobium } & $\mathrm{C} / \mathrm{R}(7)$ & & & & & & & & $-(7)$ \\
\hline & $\mathrm{C} / \mathrm{R}(12)$ & & & & & & & & \\
\hline \multirow[t]{3}{*}{ Bifidobacterium } & $\mathrm{R}(3)$ & $+^{\mathrm{b}}(5)$ & L (13) & $-(5)$ & $+(5)$ & & $-(5)$ & $-(5)$ & $-(5)$ \\
\hline & $\mathrm{R}(5)$ & $+^{\mathrm{b}}(13)$ & & $-(13)$ & $+(13)$ & & $-(13)$ & $-(13)$ & $-(13)$ \\
\hline & $\mathrm{R}(13)$ & & & & & & & & \\
\hline \multirow[t]{3}{*}{ Brochothrix } & $\mathrm{C} / \mathrm{R}^{\mathrm{d}}(11)$ & $-(15)$ & $\mathrm{L}(15)$ & & $-^{f}(20)$ & & & & $+(20)$ \\
\hline & $\mathrm{R}^{\mathrm{d}}(17)$ & $-(22)$ & $\mathrm{L}(20)$ & & $-^{f}(21)$ & & & & $+(21)$ \\
\hline & $\mathrm{R}(21)$ & - & $\mathrm{L}(21)$ & & & & & & $+(22)$ \\
\hline \multirow[t]{3}{*}{ Carnobacterium } & $\mathrm{R}(2)$ & $+^{\mathrm{e}}(2)$ & $\mathrm{L}(2)$ & $+(2)$ & $-(10)$ & $-(2)$ & & $-(19)$ & $-(6)$ \\
\hline & R (19) & $-^{e}(4)$ & $\mathrm{L}(10)$ & $+(19)$ & $-(19)$ & $-(10)$ & & & $-(19)$ \\
\hline & $\mathrm{R}(23)$ & $+(19)$ & $\mathrm{L}(23)$ & $+(23)$ & $-(23)$ & $-(23)$ & & & \\
\hline \multirow[t]{3}{*}{ Enterococcus } & $\mathrm{C}(2)$ & $-(2)$ & $\mathrm{L}(2)$ & $+(2)$ & $+(2)$ & $-(2)$ & $+(2)$ & & $-(16)$ \\
\hline & $\mathrm{C}(16)$ & $-(16)$ & L (4) & $+(10)$ & $+(10)$ & $-(10)$ & $+(10)$ & & $-(19)$ \\
\hline & C (19) & $-(19)$ & L (16) & $+(16)$ & $+(18)$ & $-(23)$ & $+(23)$ & & \\
\hline \multirow[t]{3}{*}{ Lactobacillus } & $\mathrm{R}(2)$ & $\pm(2)$ & $\mathrm{D}, \mathrm{L}, \mathrm{DL}(2)$ & $\pm(2)$ & $\pm(2)$ & $-(2)$ & $\pm(2)$ & $+(19)$ & $-(9)^{g}$ \\
\hline & $\mathrm{R}(19)$ & $\pm(18)$ & D, L, DL (10) & $\pm(10)$ & $\pm(19)$ & $-(10)$ & $\pm(10)$ & & $-(19)^{g}$ \\
\hline & $\mathrm{R}(23)$ & $\pm(19)$ & D, L, DL (23) & $\pm(23)$ & $\pm(23)$ & $-(23)$ & $\pm(23)$ & & \\
\hline \multirow[t]{3}{*}{ Lactococcus } & C (18) & $-(18)$ & L (16) & $+(10)$ & $-(10)$ & $-(10)$ & $\pm(10)$ & & $-(5)$ \\
\hline & C (19) & $-(19)$ & $\mathrm{L}(22)$ & $+(18)$ & $-(18)$ & $-(23)$ & $\pm(23)$ & & $-(16)$ \\
\hline & $\mathrm{C}(23)$ & $-(23)$ & $\mathrm{L}(23)$ & $+(23)$ & $-(23)$ & & & & $-(19)$ \\
\hline \multirow[t]{3}{*}{ Leuconostoc } & $\mathrm{C}(2)$ & $+(2)$ & $\mathrm{D}(2)$ & $+(2)$ & $-(2)$ & $-(2)$ & $\pm(2)$ & & $-(4)$ \\
\hline & C (19) & $+(19)$ & D (18) & $+(19)$ & $\pm(19)$ & $-(10)$ & $\pm(10)$ & & $-(8)$ \\
\hline & $\mathrm{C}(23)$ & $+(23)$ & $\mathrm{D}(23)$ & $+(23)$ & $-(23)$ & $-(23)$ & $\pm(23)$ & & $-(19)$ \\
\hline \multirow[t]{3}{*}{ Oenococcus } & $\mathrm{C}(2)$ & $+(2)$ & $\mathrm{D}(2)$ & $+(2)$ & $-(2)$ & $-(2)$ & $\pm(2)$ & & $-(4)$ \\
\hline & $\mathrm{C}(10)$ & $+(19)$ & D (4) & $+(19)$ & $\pm(19)$ & $-(10)$ & $\pm(10)$ & & $-(14)$ \\
\hline & C (19) & $+(23)$ & $\mathrm{D}(23)$ & $+(23)$ & $-(23)$ & $-(23)$ & $\pm(23)$ & & \\
\hline \multirow[t]{3}{*}{ Pediococcus } & $\mathrm{C}^{\mathrm{a}}(18)$ & $-(2)$ & L, DL (2) & $\pm(2)$ & $\pm(2)$ & $-(2)$ & $+(2)$ & & $-(5)$ \\
\hline & $\mathrm{C}^{\mathrm{a}}(19)$ & $-(10)$ & L, DL (4) & $\pm(19)$ & $\pm(16)$ & $-(10)$ & $+(10)$ & & $-(16)$ \\
\hline & $C^{\mathrm{a}}(23)$ & $-(23)$ & L, DL (23) & $\pm(23)$ & $\pm(23)$ & $-(23)$ & $+(23)$ & & $-(19)$ \\
\hline \multirow[t]{3}{*}{ Streptococcus } & $\mathrm{C}(2)$ & $-(2)$ & L (2) & $-(2)$ & $\pm(2)$ & $-(2)$ & $-(2)$ & & $-(5)$ \\
\hline & $\mathrm{C}(10)$ & $-(19)$ & L (10) & $-(19)$ & $\pm(19)$ & $-(10)$ & $-(10)$ & & $-(19)$ \\
\hline & C (19) & $-(23)$ & L (23) & $-(23)$ & $\pm(23)$ & $-(23)$ & $-(23)$ & & \\
\hline \multirow[t]{3}{*}{ Tetragenococcus } & $\mathrm{C}^{\mathrm{a}}(2)$ & $-(2)$ & $\mathrm{L}(2)$ & $+(2)$ & $-(2)$ & $+(2)$ & $-(2)$ & $-^{c}(19)$ & $-(19)$ \\
\hline & $C^{a}(19)$ & $-(10)$ & L (10) & $+(10)$ & $-(10)$ & $+(10)$ & $-(10)$ & & \\
\hline & $C^{a}(23)$ & $-(19)$ & & $+(23)$ & $-(23)$ & $+(23)$ & $-^{c}(19)$ & & \\
\hline \multirow[t]{3}{*}{ Vagococcus } & $\mathrm{C}(2)$ & $-(2)$ & L (2) & $+(2)$ & $-(2)$ & $-(2)$ & $\pm(2)$ & & $-(19)$ \\
\hline & C (19) & $-(10)$ & $\mathrm{L}(10)$ & $+(19)$ & $-(19)$ & $-(10)$ & $\pm(10)$ & & \\
\hline & $\mathrm{C}(23)$ & $-(19)$ & & $+(23)$ & $-(23)$ & $-(23)$ & & & \\
\hline \multirow[t]{3}{*}{ Weissella } & $\mathrm{C} / \mathrm{R}(2)$ & $+(2)$ & $\mathrm{D}, \mathrm{DL}(2)$ & $+(2)$ & $-(2)$ & $-(2)$ & $\pm(2)$ & & $-(8)$ \\
\hline & $\mathrm{C} / \mathrm{R}(8)$ & $+(8)$ & $\mathrm{D}, \mathrm{DL}(10)$ & $+(10)$ & $-(10)$ & $-(10)$ & $\pm(10)$ & & $-(16)$ \\
\hline & $\mathrm{C} / \mathrm{R}(10)$ & $+(23)$ & D, DL (23) & $+(23)$ & $-(23)$ & $-(23)$ & $\pm(23)$ & & $-(19)$ \\
\hline
\end{tabular}

C: cocci; R: rod-shape; L, D and LD: optical isomers; +: positive; -: negative; a: cocci may also be tetrad formation; b: differ from bacterial homo and heterofermentadoras on fermentation of glucose, which occurs via fructose-6-phosphate; c: grow not occur at pH 5.0 or lower; d: in older cultures the rod may give rise to coccoid forms, which develop into rod forms when subcultured onto a situable medium; e: small amounts of $\mathrm{CO}_{2}$ from glucose can be produced; f: growth not occur at $37^{\circ} \mathrm{C}$; g: can be present pseudocatalse activity.

References: (1) Aguirre and Collins, 1992; (2) Axelsson, 2004; (3) Ballongue, 2004; (4) Björkroth and Holzapfel, 2006; (5) Botelho, 2005; (6) Collins et al., 1987; (7) Collins and Wallbanks, 1992; (8) Collins et al., 1993; (9) Engesser and Hammes, 1994; (10) Inês et al., 2008; (11) Kilcher et al., 2010; (12) Linhares et al., 2010; (13) Mazo et al., 2009; (14) Mills et al., 2005; (15) Pin et al., 2002; (16) Potes and Marinho, 2007; (17) Rattanasomboon et al. (1999); (18) Schillinger and Lücke, 1989; (19) Silva et al., 2010; (20) Sneath and Jones, 1976; (21) Sneath, 2009; (22) Stiles and Holzapfel, 1997; (23) Wright and Axelsson, 2011. 


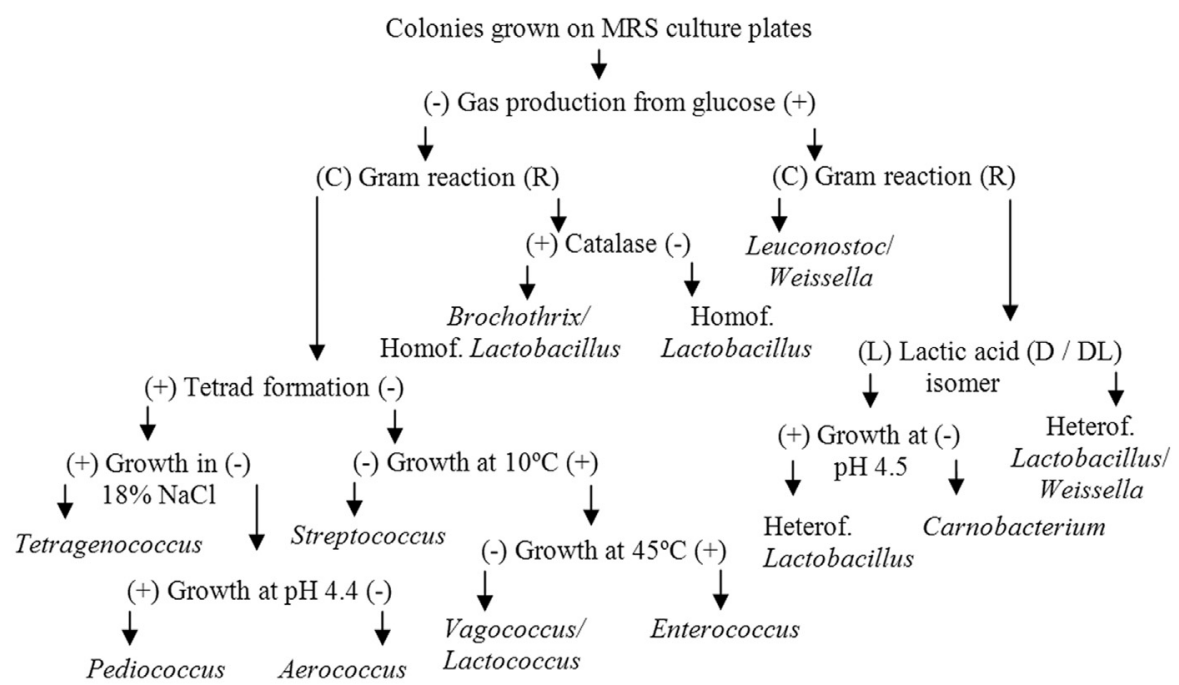

Figure 1 - Flowchart for identification of LAB genera by phenotypic characteristics. C: cocci; R: rods; (-): negative; (+): positive; L, D and DL: optical isomers. The flowchart was adapted from Schillinger and Lücke (1989).

of gas production from glucose: catalase activity was tested by addition of hydrogen peroxide $3 \%$ (Oliveira et al., 2008; Marty et al., 2012); growth at $10^{\circ} \mathrm{C}$ for 7 days, and at $45^{\circ} \mathrm{C}$ for $48 \mathrm{~h}$, were tested in MRS broth with $0.02 \mathrm{~g} / \mathrm{L}$ of bromocresol purple (Hall et al., 2001; Potes and Marinho, 2007; Wu et al., 2012); growth in $18 \% \mathrm{NaCl}$ added bromocresol purple $0.02 \mathrm{~g} / \mathrm{L}$ at MRS broth were tested at $30^{\circ} \mathrm{C}$ for $48 \mathrm{~h}$ (Hall et al., 2001; Wu et al., 2012; growth at $\mathrm{pH} 4.4 \mathrm{e}$ 4.5 in MRS broth adjusted to correct $\mathrm{pH}$ by the addition $1 \mathrm{M}$ $\mathrm{HCl}$ (Schillinger and Lücke, 1989) were incubated at $30^{\circ} \mathrm{C}$ for $48 \mathrm{~h}$; determination of lactic acid isomer formed (L, D or DL) was performed using an enzymatic-colorimetric kit (R-Biopharm, 11112821035, Darmstadt, Germany) according to the indication of the supplier. The reagents used were of analytical reagent grade.

\section{Molecular analysis}

The investigation of the spoilage bacteria of cooked cured meat products has been carried out, mostly depended on traditional microbiological methods, based on plate counts, isolation and biochemical identification (Hu et al., 2009).

The samples tested for the production of gas from glucose were streaked on MRS agar slants, incubated at $30{ }^{\circ} \mathrm{C}$ for $48 \mathrm{~h}$ into anaerobic jars (Permution, Paraná, Brazil). From this point the molecular analysis followed the method previously developed by Kullen et al. (2000). LAB DNA was extracted from the colonies grown on the MRS slants, and was deposited onto the base of a sterile microcentrifuge tube and microwaved for $6 \mathrm{~min}$ at $900 \mathrm{~W}$. Immediately following PCR reagents were added directly to the microcentrifuge tube containing the colony and thermal cycling proceeded. The Primers plb16 (5' AGAGTTTGATCCTGGCTCAG 3') and mlb16 (5', GGCTGCTGGCACGTAGTTAG 3') were used to direct
PCR amplification of a $500 \mathrm{bp}$ portion of the 16S rRNA gene. Amplification of DNA was performed in a GeneAmp ${ }^{\circledR}$ PCR System 2400 thermal cycler (Perkin Elmer, Foster City, USA) programmed for $5 \mathrm{~min}$ at $94^{\circ} \mathrm{C}$ (initial denaturation) and 35 cycles of $15 \mathrm{~s}$ at $94{ }^{\circ} \mathrm{C}$ (denaturation), $15 \mathrm{~s}$ at $55^{\circ} \mathrm{C}$ (annealing), $1 \mathrm{~min}$ at $72{ }^{\circ} \mathrm{C}$ (extension) and $10 \mathrm{~min}$ at $72^{\circ} \mathrm{C}$ (final extension). Reaction products were resolved by electrophoresis in $1.0 \%(\mathrm{w} / \mathrm{v})$ agarose gels and visualized by ethidium bromide staining. PCR products were sent to a commercial sequencing facility (Center of Nuclear Energy in Agriculture). Bacterial sequences were compared to the sequences reported in GenBank, using the BLAST (Basic Local alignment Search Tool) algorithm. The nucleotide sequences determined in this study have been assigned Genbank Accession Numbers EU855223, JF756088, GU591801, AB124845 and AB023244.

\section{Results}

\section{Isolation and enumeration of total LAB}

The results of plate counts on MRS agar showed that the LAB was present in high counts in sliced vacuum-packed cooked ham. The typical colonies grown on MRS agar plate were white, circular and slightly convex, with small diameter $(0.5-2.0 \mathrm{~mm})$. In most ways, they use up the sugars and produce too much acid, which inhibits their growth before the colonies become large. The results of the LAB counting for the 4 batches analyzed are detailed in Table 2 .

\section{Phenotypic analysis}

Through the phenotypic characterization of the LAB present in samples of sliced vacuum-packed cooked ham, it was verified that the microbiota present were heterogeneous. Of the 15 colonies subcultured to each batch, four presumptive genera were observed at one day of storage: 
Leuconostoc/Weissella sp., Enterococcus sp. and homofermentative Lactobacillus sp. (Table 3).

By the results shown in Table 3, it can be verified that at 1 day of storage, the Leuconostoc/Weissella sp. showed to be the predominant genera in batch 1,2 and 4, and in the batch 3, the Enterococcus sp. was the predominant LAB. However, with the advance in storage time, the homofermentative Lactobacillus sp. showed greater abilities to develop, being the predominant genera at 45 days of storage at $4{ }^{\circ} \mathrm{C}$ (batches 2,3 and 4 ) and $8{ }^{\circ} \mathrm{C}$ (batch 2 and 3), followed by Leuconostoc/Weissella sp., predominant at $4{ }^{\circ} \mathrm{C}$ in batch 1 and at $8{ }^{\circ} \mathrm{C}$ in batches 1 and 4 (Table 4).

It was found that the batches 1 and 4 showed loss of vacuum-packaging, and the predominantly genera belong to Leuconostoc/Weissella sp. For batches 2 and 3 that did not present loss of vacuum, homofermentative Lactobacillus sp. were predominantly identified. Both genera showed the production of milky exudates and after 45 days of storage, this change shows economical importance in the spoilage of vacuum-packaged sliced cooked ham, mainly due to changes that cause in the substrate.

Table 2 - Results of plate count for LAB at the time 1 day and 45 days of storage at $4{ }^{\circ} \mathrm{C}$ and $8{ }^{\circ} \mathrm{C}$.

\begin{tabular}{lccc}
\hline Batch & $\begin{array}{c}\text { Time 1 day } \\
(\log \mathrm{cfu} / \mathrm{g})\end{array}$ & $\begin{array}{c}\text { Time } 45 \text { days } \\
(\log \mathrm{cfu} / \mathrm{g})-4{ }^{\circ} \mathrm{C}\end{array}$ & $\begin{array}{c}\text { Time } 45 \text { days } \\
(\log \mathrm{cfu} / \mathrm{g})-8{ }^{\circ} \mathrm{C}\end{array}$ \\
\hline 1 & $1.77 \pm 0.34$ & $7.95 \pm 0.09$ & $8.59 \pm 0.04$ \\
2 & $1.67 \pm 0.35$ & $7.36 \pm 0.12$ & $8.12 \pm 0.08$ \\
3 & $2.08 \pm 0.07$ & $6.62 \pm 1.55$ & $7.74 \pm 0.43$ \\
4 & $2.41 \pm 0.10$ & $8.44 \pm 0.10$ & $8.53 \pm 0.12$ \\
Mean* & $1.98 \pm 0.37^{\mathrm{a}}$ & $7.59 \pm 0.97^{\mathrm{b}}$ & $8.25 \pm 0.41^{\mathrm{c}}$ \\
\hline
\end{tabular}

*Means with different letters are statistically different $(\mathrm{p} \leq 0.05)$ by the Tukey test; $\mathrm{n}=3$.

\section{Molecular analysis}

The molecular analysis showed that the predominant Lactobacillus species present in sliced cooked ham samples at 45 days of storage, at $4{ }^{\circ} \mathrm{C}$ and $8{ }^{\circ} \mathrm{C}$, were Lactobacillus curvatus (strain CTSPL4, access number EU855223 and strain MFPA15D06-03, access number JF756088) corresponding to $67 \%$ of the total Lactobacillus genus at $4{ }^{\circ} \mathrm{C}$ and $8{ }^{\circ} \mathrm{C}$, followed by $13 \%$ of Lactobacillus sakei (strain Moo1, access number GU591801 and strain HS-1, access number AB124845). The genus Leuconostoc/Weissella were the second predominant genus of LAB, in this case the main specie was Leuconostoc mesenteroides (strain NCBF 529, access number AB023244).

\section{Discussion}

The count of the initial population of LAB present in the samples (1.98 log cfu/g) were significant influenced by storage temperature; growth values around $7.59 \mathrm{log} \mathrm{cfu} / \mathrm{g}$ at $4{ }^{\circ} \mathrm{C}$ and $8.25 \log \mathrm{cfu} / \mathrm{g}$ at $8{ }^{\circ} \mathrm{C}$ were detected (Table 2) whose values were statistically different ( $p \leq 0.05$, by the Tukey test). The colonies present in the plates are white because do not produce pigments and are small, because the fermentation of carbohydrates does not release much energy (Massaguer, 2006). The growth of LAB reaches up to approximately 8 or $9 \log \mathrm{cfu} / \mathrm{g}$, since at this point, their growth is eventually inhibited by the amount of acid produced or lack of nutrients, mainly in cooked ham, which has a lower carbohydrate concentration in the formulation. Samples of sliced cooked ham stored at $4{ }^{\circ} \mathrm{C}$, at times 0,3 , $7,15,25$ and 35 days, showed respective LAB plates counts: not detected; $6.04 ; 6.68 ; 8.63 ; 8.67$; and $8.51 \mathrm{log}$ $\mathrm{cfu} / \mathrm{g}$, which demonstrate the rapid development of LAB (Hu et al., 2009). The LAB dominates the total viable microbiota in sliced cooked ham after a short storage time, independent of the storage temperature (assessed from 2 to

Table 3 - Results of phenotypic characteristics of LAB isolated in samples of sliced vacuum-packed cooked ham and related genera identified on the time 1 day.

\begin{tabular}{cccccccc}
\hline Batch & $\begin{array}{c}\text { Number of } \\
\text { colonies tested }\end{array}$ & $\mathrm{CO}_{2}$ & Morphology & Catalase activity & $\begin{array}{c}\text { Growth at } \\
10^{\circ} \mathrm{C}\end{array}$ & $\begin{array}{c}\text { Growth at } \\
4{ }^{\circ} \mathrm{C}\end{array}$ & Genera identified \\
\hline $1^{*}$ & 5 & - & Rods & - & $\mathrm{NT}$ & $\mathrm{NT}$ & Homofermentative Lactobacillus sp. \\
& 8 & + & Cocci & $\mathrm{NT}$ & $\mathrm{NT}$ & $\mathrm{NT}$ & Leuconostoc/Weissella sp. \\
$2^{*}$ & 2 & - & Cocci & $\mathrm{NT}$ & +0 & + & Enterococcus sp. \\
& 1 & - & Rods & - & $\mathrm{NT}$ & $\mathrm{NT}$ & Homofermentative Lactobacillus sp. \\
& 9 & + & Cocci & $\mathrm{NT}$ & $\mathrm{NT}$ & $\mathrm{NT}$ & Leuconostoc/Weissella sp. \\
3 & 11 & - & Cocci & $\mathrm{NT}$ & + & + & Enterococcus sp. \\
& 1 & - & Rods & - & $\mathrm{NT}$ & $\mathrm{NT}$ & Homofermentative Lactobacillus sp. \\
& 3 & + & Cocci & $\mathrm{NT}$ & $\mathrm{NT}$ & $\mathrm{NT}$ & Leuconostoc/Weissella sp. \\
& 2 & - & Rods & - & $\mathrm{NT}$ & $\mathrm{NT}$ & Homofermentative Lactobacillus sp. \\
& 13 & + & Cocci & $\mathrm{NT}$ & $\mathrm{NT}$ & $\mathrm{NT}$ & Leuconostoc/Weissella sp. \\
\hline
\end{tabular}

+: positive; -: negative; NT: not tested; * The number of colonies grown in each plate of triplicate was lower than 5. 
Table 4 - Results of phenotypic characteristics of LAB isolated in samples of sliced vacuum-packed cooked ham and related genera identified on the time 45 day.

\begin{tabular}{|c|c|c|c|c|c|}
\hline Batch & Number of colonies tested & $\mathrm{CO}_{2}$ & Morphology & Catalase activity & Genera identified \\
\hline \multicolumn{6}{|c|}{ Time 45 days at $4{ }^{\circ} \mathrm{C}$} \\
\hline \multirow[t]{2}{*}{1} & 1 & - & Rods & - & Homofermentative Lactobacillus sp. \\
\hline & 14 & + & Cocci & NT & Leuconostoc/Weissella sp. \\
\hline 2 & 15 & - & Rods & - & Homofermentative Lactobacillus sp. \\
\hline 3 & 15 & - & Rods & - & Homofermentative Lactobacillus sp. \\
\hline \multirow[t]{2}{*}{4} & 13 & - & Rods & - & Homofermentative Lactobacillus sp. \\
\hline & 2 & + & Cocci & NT & Leuconostoc/Weissella sp. \\
\hline \multicolumn{6}{|c|}{ Time 45 days at $8^{\circ} \mathrm{C}$} \\
\hline \multirow[t]{2}{*}{1} & 2 & - & Rods & - & Homofermentative Lactobacillus sp. \\
\hline & 13 & + & Cocci & NT & Leuconostoc/Weissella sp. \\
\hline 2 & 15 & - & Rods & - & Homofermentative Lactobacillus sp. \\
\hline 3 & 15 & - & Rods & - & Homofermentative Lactobacillus sp. \\
\hline \multirow[t]{2}{*}{4} & 6 & - & Rods & - & Homofermentative Lactobacillus sp. \\
\hline & 9 & + & Cocci & NT & Leuconostoc/Weissella sp. \\
\hline
\end{tabular}

+: positive; -: negative; NT: not tested.

$15^{\circ} \mathrm{C}$ ), and when plate counts was around $7 \log \mathrm{cfu} / \mathrm{g}$, the product reaches the end of shelf life, which was indicated by changes in sensory quality and $\mathrm{pH}$ decrease (Kreyenschmidt et al., 2010). Sliced cooked ham at time 0, 30 and 90 days of storage at $4{ }^{\circ} \mathrm{C}$ showed plate counts around 4.65 , 8.72 and $7.27 \log \mathrm{cfu} / \mathrm{g}$, respectively (Han et al., 2011). Similar results were found for the quantification of LAB on four batches of sliced vacuum-packaged cooked ham.

Bacteria associated with the spoilage of refrigerated meat products causing defects such as off-odors, off-flavors, discoloration, gas production, slime production and decrease in $\mathrm{pH}$, consist of $B$. thermosphacta, Carnobacterium spp., Lactobacillus spp., Leuconostoc spp. and Weissella spp. (Borch et al., 1996). In the four batches studied in this work, the formation of milky exudates was observed at 45 days of storage; for the batches 1 and 4 was also observed gas production $\left(\mathrm{CO}_{2}\right)$ from the fermentation of carbohydrates by heterofermentative LAB, in addition to the loss of vacuum packaging. The differences between homofermentative and heterofermentative LAB have a genetic and physiological basis; the homofermentative have aldolase and hexose isomerase enzymes, but do not exhibit the phosphoketolase and use the Embden-Meyerhof-Parnas pathway to produce two molecules of lactic acid from a glucose molecule, while the heterofermentative have the phosphoketolase, but not aldolase and hexose isomerase enzyme, so they use hexosemonophosphate pathway or pentose degradation of glucose to produce lactic acid, ethanol and carbon dioxide (Axelsson, 2004; Landgraf, 2008).

In the industrial practice of vacuum-packed meat products is common to observe that when the LAB counts exceeds $7 \mathrm{log} \mathrm{cfu} / \mathrm{g}$ the alterations become perceptive on substrate, among which the slightly acid flavor, the presence of milky exudates and loss of vacuum (only when refers to heterofermentative LAB). These changes were perceptible in samples of sliced vacuum-packed cooked ham, and the vacuum loss was only noted in samples with a predominance of Leuconostoc/Weissella sp. The milky exudates, loss of vacuum, and discoloration are the most important changes provided by LAB that affect the purchase decision of a consumer, because reach the appearance of product negatively.

Among the 15 genera listed in Table 1, this study involved the identification of 12 genera. The genera Atopobium, Bifidobacterium and Oenococcus were not included in this study because their peculiar characteristics. The genus Atopobium is related with human's infections, especially women vaginal infections and is uncommon in food microbiology (Libby et al., 2008). The genus Bifidobacterium is grouped with the LAB and shares a few characteristics, however is phylogenetically unrelated (Hall et al., 2001; Axelsson, 2004). This genus differs from LAB on the mode of glucose fermentation, which occurs via fructose-6-phosphate, because the presence of the enzyme fructose-6-phosphate phosphoketolase (Mazo et al., 2009). The genus Oenococcus, which consists an only one specie, Oenococcus oeni, is easily distinguished from other genera because their glycosylated derivative of pantothenic acid requirement; this substance can found in tomato juice (Silva et al., 2010).

According to Table 3, the samples of vacuumpackaged sliced cooked ham were colonized initially by Leuconostoc/Weissella sp. (60\%), Enterococcus sp. (24\%) and homofermentative Lactobacillus sp. (16\%). At 45 days of storage at $4{ }^{\circ} \mathrm{C}$ and $8{ }^{\circ} \mathrm{C}$, the predominant LAB were 
homofermentative Lactobacillus sp. $\left(73 \%\right.$ at $4{ }^{\circ} \mathrm{C}$ and $63 \%$ at $\left.8{ }^{\circ} \mathrm{C}\right)$ followed by Leuconostoc/Weissella sp. $(27 \%$ at $4{ }^{\circ} \mathrm{C}$ and $37 \%$ at $8{ }^{\circ} \mathrm{C}$ ), according Table 4 . Among then, the predominant species were Lactobacillus curvatus (strain CTSPL4, and MFPA15D06-03), Lactobacillus sakei (strain Moo1 and HS-1) and Leuconostoc mesenteroides (strain NCBF 529).

The Enterococcus sp. was present in two samples at the beginning of the shelf life but showed no growth after 45 days of storage at $4{ }^{\circ} \mathrm{C}$ and $8{ }^{\circ} \mathrm{C}$. This genus is widely distributed in the environment, especially inhabiting the human and animal gastrointestinal tract (Foulquié-Moreno et al., 2006). The results observed in this work are similar to those found by Ammor et al. (2005) whose showed that Lactobacillus sakei was the predominant LAB present in traditional fermented dry sausage at one and nine weeks of storage; however, also Enterococcus faecium and Enterococcus spp. were present at the first time, but absent at 9 weeks. Similarly, Marty et al. (2102) analyzed 21 samples of spontaneously fermented Swiss meat products, founding that Lactobacillus accounted for $76 \%$ of the LAB present, being the Lactobacillus sakei and Lactobacillus curvatus the predominant species, followed by $18.3 \%$ of the genus Enterococcus sp., and 2.9\% of both Pediococcus sp. and Streptococcus sp. The Enterococcus resistance to pasteurization temperatures, and their adaptability to different substrates and growth conditions (low and high temperature, extreme $\mathrm{pH}$, and salinity) implies that they can be found either in food products manufactured from raw materials (milk or meat) and in heat-treated food products, because the heating of processed meats during production may confer a selective advantage to Enterococcus, since this bacteria are the most thermotolerant among of the nonsporulating bacteria (Foulquié-Moreno et al., 2006).

The LAB are devoid of a "true" catalase and cytochromes when grown in laboratory growth media, which lack heme or related compounds (Axelsson, 2004), but some species of Lactobacillus can present a pseudocatalase activity (Engesser and Hammes, 1994). Since this, the proposed classification to separate the genus homofermentative Lactobacillus and Brochothrix from the catalase test may result an overlap in the case of positive reaction. It is known that the species of Brochothrix produce catalase, but a few Lactobacillus can also produce it. If a negative reaction of catalase it is found can be conclude that Lactobacillus is the only genera present, like as the result showed.

The Lactobacillus genus is a heterogeneous group of $\mathrm{LAB}$ with important implications in food fermentation. The ability to colonize a variety of habitats is a direct consequence of the wide metabolic versatility of this group of LAB (Axelsson, 2004; Giraffa et al., 2010). This genus is one of the original LAB genera and several species of importance in foods have been reclassified in new genera, among: Carnobacterium (Collins et al., 1987); Weissella
(Collins et al., 1993); and Atopobium (Collins and Wallbanks, 1992). Members of the genus were subdivided in three groups: group I - the obligatory homofermentative who include species like Lactobacillus acidophilus, Lactobacillus delbrückii, Lactobacillus helveticus and Lactobacillus salivarius; group II - the facultative heterofermentative that include species like Lactobacillus casei, Lactobacillus curvatus, Lactobacillus plantarum and Lactobacillus sakei; and the group III - the obligatory heterofermentative who include the species like Lactobacillus brevis, Lactobacillus buchneri, Lactobacillus fermentum and Lactobacillus reuteri (Axelsson, 2004). In this work the genera Lactobacillus curvatus (strains CTSPL4 and MFPA15D06-03) and Lactobacillus sakei (strains Moo1 and HS-1) were the predominant spoilage LAB, and according to Axelsson (Axelsson, 2004) they are facultative heterofermentative, who were identified like homofermentative Lactobacillus by the phenotypic identification. These genera normally do not produce gas from glucose; however in singular conditions they can produce it. Commonly occur confound on phenotypic characteristics among Leuconostoc, Weissella, facultative heterofermentative and obligatory heterofermentative Lactobacillus. In this work, phenotypic analysis did not allow the identification of the genera Weissella and Leuconostoc, due to overlap; in this case the molecular analysis allowed the identification of the correctly specie, classified by phenotypic analyses like Leuconostoc/Weissella sp., and identified as Leuconostoc mesenteroides (strain NCBF 529) by molecular analyses. In this way, molecular analysis was really useful for the identification of LAB from sliced vacuum-packed cooked ham. These results are similar to those previously reported by $\mathrm{Hu}$ et al. (2009). Leuconostoc were able to growth at $8{ }^{\circ} \mathrm{C}$ (Hemme and Foucaud-Scheunemann, 2004), but Leuconostoc mesenteroides is also able to growth at $4{ }^{\circ} \mathrm{C}$. As Lactobacillus, the genus Leuconostoc is linked to a few negative aspects including spoilage in meat products. The presence of LAB in vacuum packaged meats and similar products such as sausages; among them, the genera Lactobacillus and Leuconostoc were cited as participants in the deterioration of meat packed in vacuum or modified atmosphere, causing surface slime and aroma of fermented (Landgraf, 2008; Silva et al., 2010). Strains of LAB generally regarded as natural in meat and meat products are Lactobacillus sakei, Lactobacillus curvatus, Lactobacillus plantarum, Carnobacterium divergens, Carnobacterium maltaromaticum and Weissella viridescens (Ammor et al., 2005). Similarly to the results founded in this work, Hu et al. (2009) showed that the dominant spoilage bacteria in sliced vacuum-packed cooked ham were Lactobacillus sakei and Lactobacillus curvatus, and Leuconostoc genus were minor components. During the cold storage, development of Leuconostoc species is favored in vacuum packed samples, while Weissella viridescens is predominant when 
the products is pasteurized after packing (Santos et al., 2005). The sliced vacuum-packed cooked ham is not a pasteurized meat product after packing, is only a vacuumpacked, in this way, the results observed in this work are in agreement with the results founded by these authors.

Phenotypic characterization based on sugar fermentation pattern and conventional phenotypic properties may not always provide sufficient basis for the reliable identification of LAB, although it is a useful tool for presumptive classification (Santos et al., 2005).

The differentiation between the genera Leuconostoc and Weissella, and heterofermentative Lactobacillus and Weissella are not possible by means of phenotypic methods. After Collins et al. (1993) subdivided the genera Leuconostoc into a new genus called Weissella, the phenotypic methodologies can only describe the Leuconostoc family, than include the genera Leuconostoc, Oenococcus and Weissella (Chelo et al., 2007). Similarly overlaps occurred with the genera Lactococcus and Vagococcus. The genera Vagococcus was created by Collins et al. (1989) to accommodate new specie with all the features of Lactococcus but also peritrichous flagella (Silva et al., 2010). In such cases the molecular analysis allows identification of the genus and even species level. Because this, identification of the LAB species selected was performed by DNA sequences of the 16S rRNA.

\section{Conclusions}

The LAB initially present in the samples showed plate counts around $1.98 \log \mathrm{cfu} / \mathrm{g}$, and after 45 days of storage were influenced by storage temperature, rising to values of $7.59 \mathrm{log} \mathrm{cfu} / \mathrm{g}$ at $4{ }^{\circ} \mathrm{C}$ and $8.25 \mathrm{log} \mathrm{cfu} / \mathrm{g}$ at $8{ }^{\circ} \mathrm{C}$. The dominant spoilage bacteria of sliced vacuum-packed cooked ham on time 45 day of storage are Lactobacillus curvatus (strains CTSPL4 and MFPA15D06-03) and Lactobacillus sakei (strains Moo1 and HS-1), and the Leuconostoc mesenteroides (strain NCBF 529) was a minor component. The quantification and phenotypic methodologies combined with molecular methodologies of LAB identification are helpful to better understand the growth and activity of spoilage microorganisms of sliced vacuumpacked cooked ham. The evolution of sliced vacuumpacked cooked ham microbiota may be important for select the main deteriorating LAB aiming inhibit these microorganisms by future studies.

\section{Acknowledgments}

The authors would like to thank Center for Nuclear Energy in Agriculture/USP and especially Dr. Siu Mui Tsai of the Laboratory of Molecular Biology for the identification of the LAB species described in this work.

\section{References}

Aguirre M, Collins MD (1992) Phylogenetic analyses of some Aerococcus-like organisms from urinary tract infections: description of Aerococcus urinae sp. nov. J Gen Microbiol 138:401-405.

Ammor S, Rachaman C, Chaillou S, Prévost H, Dousset X, Zagorec M, Dufour E, Chevallier I (2005) Phenotypic and genotypic identification of lactic acid bacteria isolated from a smallscale facility producing traditional dry sausages. Food Microbiol 22:373-382.

Audenaert K, D’Haene K, Messens K, Ruyssen T, Vandamme P, Huys G (2010) Diversity of lactic acid bacteria from modified atmosphere packaged sliced cooked meat products at sell-by date assessed by PCR-denaturing gradient gel electrophoresis. Food Microbiol 27:12-18.

Axelsson L (2004) Acid lactic bacteria: classification and physiology. In: Salminen S, Wright AV, Ouwehand A (eds) Lactic Acid Bacteria: Microbiological and Functional Aspects. Marcel Dekker Inc, New York, pp 1-66.

Ballongue J (2004) Bifidobacteria and Probiotic Action. In: Salminen S, Wright AV, Ouwehand A (eds) Lactic Acid Bacteria: Microbiological and Functional aspects. Marcel Dekker Inc, New York, pp 67-124.

Björkroth J, Holzapfel W (2006) Genera Leuconostoc, Oenococcus and Weissella. In: Dworkin M, Falkow S, Rosenberg E, Schleifer KH, Stackebrandt E (eds) The Prokaryotes: A Handbook on the Biology of Bacteria: Firmicutes, Cyanobacteria. Springer, New York, pp 267-319.

Borch E, Kant-Muermans ML, Blixt Y (1996) Bacterial spoilage of meat and cured meat products. Int J Food Microbiol 33:103-120.

Botelho L (2005) Isolamento e Identificação de Lactobacilos e Bifidobactérias em Alimentos Probióticos Disponíveis no Mercado Brasileiro. Doctorate Thesis, Unicamp, 227 p.

Brazil (2001) Ministério da Saúde. Resolução RDC n ${ }^{\circ} 12$ de 02 de janeiro de 2001 - Aprova o Regulamento Técnico sobre padrões microbiológicos para alimentos. Diário Oficial da União, Brasília, BR, 10 de janeiro de 2001.

Chelo IM, Zé-Zé L, Tenreiro R (2007) Congruence of evolutionary relationships inside the Leuconostoc-Oenococcus-Weissella clade assessed by phylogenetic analysis of the 16S rRNA gene, dnaA, gyrB, rpoC and dnaK. Int J Syst Evol Microbiol 57:276-286.

Collins MD, Farrow JAE, Phillips BA, Ferusu S, Jones D (1987) Classification of Lactobacillus piscicola, and some catalasenegative, asporogenous, rod-shaped bacteria from poultry in a new genus, Carnobacterium. Int J Syst Bacteriol 37:310-316.

Collins MD, Ash C, Farrow JAE, Wallbanks S, Williams AM (1989) 16S Ribosomal ribonucleic acid sequence analyses of lactococci and related taxa. Description of Vagococcus fluvialis gen. nov., sp. nov. J Appl Microbiol 67:453-460.

Collins MD, Wallbanks S (1992) Comparative sequence analyses of the 16S rRNA genes of Lactobacillus minutus, Lactobacillus rimae and Streptococcus parvulus: Proposal for the creation of a new genus Atopobium. FEMS Microbiol Lett 95:235-240.

Collins MD, Samelis J, Metaxopoulos J, Wallbanks S (1993) Taxonomic studies on some leuconostoc-like organisms from fermented sausages: description of a new genus Weissella for the Leuconostoc paramesenteroides group of species. J Appl Bacteriol 75:595-603. 
Engesser DM, Hammes WP (1994) Non-heme catalase activity of lactic acid bacteria. Syst Appl Microbiol 17:11-19.

Foulquié-Moreno MR, Sarantinopoulos P, Tsakalidou E, Vuyst L (2006) The role and application of eneterococci in food and health. Int J Food Microbiol 106:1-24.

Giraffa G, Chanishvili N, Widyastuti Y (2010) Importance of lactobacilli in food and feed biotechnology. Res Microbiol 161:480-487.

Hall PA, Ledenbach L, Flowers RS (2001) Acid-producing Microorganisms. In: Downes FP, Ito $\mathrm{K}$ (eds). Compendium of Methods for the Microbiological Examination of Foods. American Public Health Association, Washington, pp 201207.

Han Y, Jiang Y, Xu X, Sun X, Xu B, Zhou G (2011) Effect of high pressure treatment on microbial populations of sliced vacuum-packed cooked ham. Meat Sci 88: 682-688.

Hemme D, Foucaud-Scheunemann C (2004) Leuconostoc, characteristics, use in dairy technology and prospects in functional foods. Int Dairy J 14:467-494.

Hu P, Zhou G, Xu X, Li C, Han Y (2009) Characterization of the predominant spoilage bacteria in sliced vacuum-packed cooked ham based on 16S rDNA-DGGE. Food Control 20:99-104.

Inês A, Tenreiro T, Tenreiro R, Mendes-Faia A (2008) Review: wine lactic acid bacteria - Part I. Ciência Téc Vitiv 23:81-96.

Jay JM (2005) Microbiologia de Alimentos. Artmed, Porto Alegre.

Kilcher S, Loessner MJ, Klumpp J (2010) Brochothrix thermosphactha bacteriophages features heterogeneous and highly mosaic genomes and utilize unique prophage insertion sites. J Bacteriol 192:5441-5453.

Kreyenschmidt J, Hübner A, Beierle E, Chonsch L, Scherer A, Petersen B (2010) Determination of the shelf life of sliced cooked ham based on the growth of lactic acid bacteria in different steps of the chain. J Appl Microbiol 108:510-520.

Kullen MJ, Sanozky-Dawes RB, Crowell DC, Klaenhammer TR (2000) Use of the DNA sequence of variable regions of the $16 \mathrm{~S}$ rRNA gene for rapid and accurate identification of bacteria in the Lactobacillus acidophilus complex. J Appl Microbiol 89:511-516.

Landgraf M (2008) Alterações químicas causadas por microrganismos. In: Franco BDGM, Landgraf M (eds). Microbiologia dos Alimentos. Atheneu, São Paulo, pp 83-92.

Libby EK, Pascal KE, Mordechai E, Adelson ME, Trama JP (2008) Atopobium vaginae triggers an innate immune response in an in vitro model of bacterial vaginosis. Microbes Infect 10:439-446.

Linhares IM, Giraldo PC, Barcat EC (2010) Novos conhecimentos sobre a flora bacteriana vaginal. Rev Assoc Med Bras 56:370-374

Marty E, Buchs J, Eugster-Meier E, Lacroix C, Meile L (2012) Identification of staphylococci and dominant lactic acid bacteria in spontaneously fermented Swiss meat products using PCR-RFLP. Food Microbiol 29:157-166.

Massaguer PR (2006) Microbiologia dos Processos Alimentares. Varela, São Paulo.

Mazo JZ, Ilha EC, Arisi ACM, Sant'anna ES (2009) Bifidobactérias: isolamento, identificação e aplicação em alimentos probióticos. Bol Ceppa 27:119-134.

Mills DA, Rawsthorne H, Parker C, Tamir D, Makarova K (2005) Genomic analysis of Oenococcus oeni PSU-1 and its relevance to winemaking. FEMS Microbiol Rev 29:465-475.
Oliveira RBP, Oliveira AL, Glória MBA (2008) Screening of lactic acid bacteria from vacuum packaged beef for antimicrobial activity. Braz J Microbiol 39:368-374.

Pin C, Fernando GDG, Ordóñez JA (2002) Effect of modified atmosphere composition on the metabolism of glucose by Brochothrix thermosphacta. Appl Environ Microbiol 68:4441-4447.

Potes ME, Marinho AA (2007) Recovery and identification of lactic acid bacteria using different culture media. Rev Port Cienc Vet 102:145-151.

Rattanasomboon N, Bellara SR, Harding CL, Fryer PJ, Thomas CR, Al-Rubeai M, McFarlane CM (1999) Growth and enumeration of the meat spoilage bacterium Brochothrix thermosphacta. Int J Food Microbiol 51:145-158.

Russo F, Ercolini D, Mauriello G, Villani F (2006) Behaviour of Brochothrix thermosphacta in presence of other meat spoilage microbial groups. Food Microbiol 23:797-802.

Santos EM, Jaime I, Rovira J, Lyhs U, Korkeala H, Björkroth J (2005) Characterization and identification of lactic acid bacteria in "morcilla de Burgos". Int J Food Microbiol 97:285-296.

Schillinger U, Lücke FK (1989) Identification of lactobacilli from meat and meat products. Food Microbiol 4:199-208.

Silva N, Junqueira VCA, Silveira NFA, Taniwaki MH, Santos RFS, Gomes RAR, Okazaki MM (2010) Manual de Métodos de Análises Microbiológica de Alimentos e Água. Varela, São Paulo.

Slongo AP, Rosenthal A, Camargo LMQ, Deliza R, Mathias SP, Aragão GMF (2009) Modeling the growth of lactic acid bacteria in sliced ham processed by high hydrostatic pressure. Food Sci Technol LEB 42:303-306.

Sneath PHA, Jones D (1976) Brochothrix, a new genus tentatively placed in the family Lactobacillaceae. Int J Syst Bacteriol 26:102-104

Sneath PHA (2009) Genus II. Brochothrix. In: Vos PD, Garrity G, Jones D, Krieg NR, Ludwing W, Rainey FA, Schleifer KH, Whitman WB (eds) Bergey's Manual of Systematic Bacteriology: The Firmicutes. Springer, New York, pp 257-268.

Stiles ME, Holzapfel WH (1997) Review article: Lactic acid bacteria of foods and their current taxonomy. Int J Food Microbiol 36:1-29.

Vercammen A, Vanoirbeek KGA, Lurquin I, Steen L, Goemaere O, Szczepaniak S, Paelinck H, Hendrickx MEG, Michiels CW (2011) Shelf-life extension of cooked ham model product by high hydrostatic pressure and natural preservatives. Innov Food Sci Emerg Technol 12:407-415.

Wright AV, Axelsson L (2011) Lactic acid bacteria: an introduction. In: Lahtinen S, Ouwehand AC, Salminen S, Wright AV (eds) Lactic Acid Bacteria: Microbiology and Functional Aspects. CRC Press, Boca Raton, pp 1-16.

Wu JJ, Ma YK, Zhang FF, Chen FS (2012) Biodiversity of yeasts, lactic acid bacteria and acetic acid bacteria in the fermentation of "Shanxi aged vinegar", a traditional Chinese vinegar. Food Microbiol 30:289-297.

Zhang H, Kong B, Xiong YL, Sun X (2009) Antimicrobial activities of spice extracts against pathogenic and spoilage bacteria in modified atmosphere packaged fresh pork and vacuum packaged ham slices stored at $4{ }^{\circ} \mathrm{C}$. Meat Sci 81:686-692.

\section{Associate Editor: Eduardo Cesar Tondo}

All the content of the journal, except where otherwise noted, is licensed under a Creative Commons License CC BY-NC. 